\title{
THE TRANSITION TO AN INNOVATIVE ECONOMY AS A STRATEGIC IMPERATIVE
}

\author{
Ravil M. Nurtdinov ${ }^{1}$ \\ Albert R. Nurtdinov ${ }^{2}$ \\ Niyaz K. Gabdrakhmanov ${ }^{3}$
}

\begin{abstract}
This paper discusses the old inertial, natural-resource growth innovation as the key to economic growth, an assessment of the innovation sphere, and justified way innovative activities of economic subjects. The experience of industrialized countries shows conclusively that sustained economic growth in modern conditions is not the result of primitive production capacity factors, but their improvement model to a predominantly innovative type of development. In this article as a hypothesis put forward the following points: innovation sphere Russia is experiencing a deep crisis; the key problem in the way of innovation activity in the country is the lack of effective mechanisms for funding research and development.
\end{abstract} and development on the basis of scientific and technological progress and innovation. To examine the strategy of Russia's development we must take into account that new trends fundamentally alter our understanding of the

Keywords: Innovation factor of economic growth, innovation financing, political financing, encouraging innovative activity, capital flight foreign investment.

mechanisms of economic growth. Russia must solve both its tactical problems and

\section{INTRODUCTION} seek answers to new challenges in order to ensure gradual, phased transition from

\footnotetext{
1 Kazan Federal University, Institute of Management, Economics and Finance. e-mail: nz99nz@yandex.ru. Tel. +7 (904) 662-60-25.

2 Kazan Federal University, Institute of Management, Economics and Finance. e-mail: nz99nz@yandex.ru.Tel.+7(904)662-60-25

3 Kazan Federal University, Institute of Management, Economics and Finance. e-mail: nz99nz@yandex.ru.Tel.+7 (904)662-60-25.
} 
The experience of industrialized countries shows conclusively that sustained economic growth in modern conditions is not the result of primitive production capacity factors, but their improvement and development on the basis of scientific and technological progress and innovation.

To examine the strategy of Russia's development we must take into account that new trends fundamentally alter our understanding of the mechanisms of economic growth. Russia must solve both its tactical problems and seek answers to new challenges in order to ensure gradual, phased transition from the old inertial, natural-resource growth model to a predominantly innovative type of development.

The aim of this work is to study the innovation sphere of Russia, to identify factors hindering innovation activity of economic agents, as well as the development of measures to address the existing problems.

As a hypothesis put forward the following points:

1) Innovation sphere Russia is experiencing a deep crisis;
2) The key problem in the way of innovation activity in the country is the lack of effective mechanisms for funding research and development.

\section{LITERATURE REVIEW}

Adam Smith theorized about scientific and technological progress and its role in economic development, although he did not see it as a relatively independent factor of production [1]. His further interest in this field later faded. Neoclassical economists believed that economic growth is determined only by the cost of labour and capital.

Since the middle of last century, there has been increasing attention in issues of scientific and technological progress. Robert Solow concludes that $87 \%$ of the U.S.'s productivity growth was due to technological progress [2]. S. Smith proves the crucial role of innovation in economic development, as well as the importance of radical technological change in the evolution of economic growth [3]. Joseph Schumpeter argues that economic development comes in the form of disharmonious jumps from developing innovative projects, and that 
innovative entrepreneurs are its main driving force [4]. M. Porter notes that competition is a powerful factor in encouraging economic agents to innovate in production, and to invest in research and development [5].

\section{METHOD}

The study used scientific methods of cognition: induction and deduction, the unity of the historical and logical analysis and synthesis, and the system of economic and statistical analysis.

\section{RESULTS}

It should be stated that Russia remains in a state of innovation crisis whose roots are, in our view, in the Communist past. At the sunset of its existence the Soviet Union failed by using command- administrative mechanisms to keep steady economic growth and improve living standards. Innovative activity declined steadily, and with the beginning of shock therapy the dismantling of the existing economic system had become critical. Transformation processes associated with the transition to a market economy pushed the problems caused by scientific and technological progress to the margins of economic policy decisions. That, along with the investment downturn, further aggravated the crisis tendencies in the economy, negatively impacting the overall situation of the industrial sector of the country.

First of all, the 1992 crisis affected the condition of fixed assets and their depreciation, which in 2012 reached $48.6 \%$, nearly double that of 1970 (25.7\%). The most problematic activities are fishing and fish farming $(64.9 \%)$, transport and communications $(58.6 \%)$, health and social services (55.3), education (54.9\%), mining (53.7 $\%)$, production and distribution of electricity, and gas and water (51.2\%) [6].

At the same time the rate of renewal of fixed assets dramatically decreased from $10.5 \%$ in 1970 to $1.8 \%$ in 2000, although in 2012 it rose, reaching $3.9 \%$, but that was insufficient. The average age of fixed assets increased from 8.4 to 26.8 years, and their disposal, in contrast, was characterized by a reduction - from $1.8 \%$ to $0.7 \%$. This could not cover periods of physical 
deterioration, and did not provide technological reliability and safety [7].

During the period of transformational recession the number of developed and established technological products related to the production of new equipment fell by more than half and those related to instruments and automation equipment fell by $60 \%$. As a result, the competitiveness of industrial products was dramatically weakened. It is understood that the domestic industrial production weakened so much that the market began to reject it and eventually turned to import substitutions. The volume of industrial manufacture declined three times, with the most significant reduction in the release of high technology products and the agricultural sector.

In the post-reform period the number of organizations involved in research and development has steadily decreased.

\section{The-number of scientific organizations and their staff}

\begin{tabular}{|l|c|c|c|c|c|c|}
\hline & & & & & \\
\hline & & & & & & \\
\hline
\end{tabular}

Figure 1: The number of scientific organizations and their staff 
The total number decreased from 4555 in 1992 to 3605 in 2013, and the share of engineering offices - much more important- decreased from 865 to 364 and design and design organizations from 495 to 38 . The number of personnel engaged in research and development decreased from 1,532,800 people in 1992 to 727,0 thousand in 2013; including researchers dropping from 992,6 thousand to 369,0 thousand [8].

The innovative activity of enterprises remains extremely low, with only one in ten introducing new and improved products and technologies in the industry. Even in moderately innovative states, enterprises produced significantly more, like Portugal - 26\%, and Greece - 29\%. The gap with the leaders is even more substantial. See: the Netherlands (62\%), Austria (69\%), Denmark (71\%), and Ireland (74\%) [9]. The coefficient of inventive activity is unsatisfactory. The number of residents filing applications for inventions per 1 million inhabitants is approximately 4.5 times lower than in Finland, Sweden, and the United States, 5.5 times lower than in Germany, 10 times than Korea, and we lose 18-19 times as many compared with Japan [9]. Inventive activity is particularly low at the final stage of the scientific and technological chain. Unlike developed countries, the number of active patents in Russia is more than 7.5 times greater than the number of utility model certificates. In Germany, for example, the ratio for patents with registration was only 1.25 [10].

One of the pronounced negative trends of innovation in Russia is low return on innovation. This is confirmed by the small fraction of innovative goods shipped in total industrial production $(4.4 \%)$. The weak performance of innovation can be judged in terms of exports of high technology products, versus, for example, Korea and Malaysia's 13 times, 38 times in Japan, and the United States' 70 times as much. The country's share in the world market of high technology products is only $0.25 \%$, compared to the U.S. accounting for 39\%, Japan's 30\%, China's 16\%, and Germany's 14\% shares [11]. Remain extremely low costs for research and development activities, amounting in $2012,1.16 \%$ of GDP. This is extremely low compared with other countries. In the U.S., it accounts for $2.90 \%, 2.82 \%$ in Germany, in Japan - 3.36 \%. Russia's economic development requires for 
research and development activities are at least $2 \%$, or preferably $3 \%$ of GDP, as is done, for example, in the new industrialized countries of Southeast
Asia [12]. Ranking of countries largest GDP and research and development activities costs are presented in Table 3 .

Table 1: Ranking of countries largest GDP and research and development activities costs

\begin{tabular}{|c|c|c|c|c|}
\hline Country & $\begin{array}{c}\text { The value of } \\
\text { GDP, mln. } \\
\text { USD }\end{array}$ & $\begin{array}{c}\text { Total expenditure on } \\
\text { research and } \\
\text { development activities, } \\
\text { mln. USD }\end{array}$ & $\begin{array}{c}\text { Research and } \\
\text { development activities } \\
\text { expenditure as \% of } \\
\text { GDP }\end{array}$ \\
\hline 1. & USA & 15685800,00 & 454882,00 & 2,9 \\
\hline 2. & China & 8227103,00 & 139860,00 & 1,7 \\
\hline 3. & Japan & 5959718,00 & 200246,00 & 3,36 \\
\hline 4. & Germany & 3399589,00 & 95868,00 & 2,82 \\
\hline 5. & France & 2612818,00 & 58788,00 & 1,76 \\
\hline 6. & United & 2435174,00 & 42859,00 & 1,16 \\
\hline 7. & Kingdom & & & 1,16 \\
\hline 8. & Russia & 2014775,00 & 23371,00 & 1,26 \\
\hline 9. & Italy & 2013263,00 & 25367,00 & \\
\hline
\end{tabular}

More than half of the total expenditures on science and the promotion of scientific and technological progress in Russia are made by the State, but the proportion of such expenditure is only $1.6 \%$ of the federal budget, or $0.57 \%$ of GDP. At the regional level the funds allocated to science are purely symbolic. For example, in the budget of the Republic of Tatarstan, the amount is equivalent to 5.5 million euros, including 0.8 million euros for basic and applied research, which is respectively $0.21 \%$ and $0.03 \%$ of the total expenditures of the Republican budget [6]. 


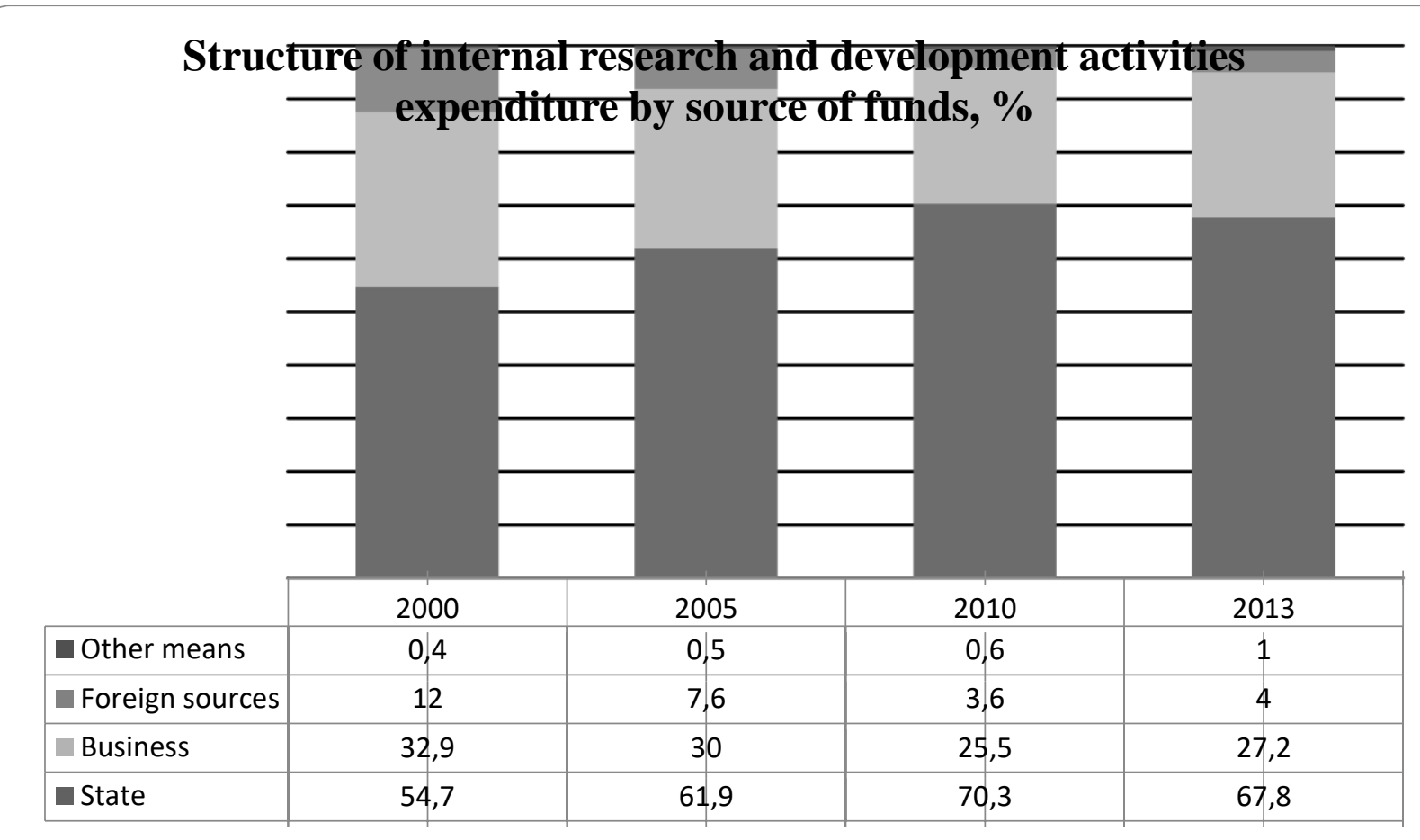

Figure 2: Structure of internal research and development activities expenditure by source of funds, \%

One consequence of the neglect of science and education has been a leak of human capital, which, during the market reforms, amounted to a variously estimated 1.3-1.5 million people. Many of our fellow citizens, part of the intellectual elite of the country, settled in the U.S., Canada, Germany, Israel, and other countries. This process not only continues unabated, but also seems to be gaining strength. All-Russian Public Opinion Research Center research results indicate that $21 \%$ of our citizens are potential emigrants, and their number in the last 20 years has quadrupled. The most determined are the youngest (39\%), the educated (29\%), and Internet users (33\%) [6].

Lack of funding research and development activities significantly reduces the effectiveness of economic development. On the basis of our proposed formula, we define in terms of value (absolute) terms, net savings, taking into account the innovative factor [7]: 


$$
\mathrm{GS}=\mathrm{GDP}-(\mathrm{ASH}+\mathrm{DFA})-
$$

$\mathrm{DFA}-\mathrm{CNR}-\mathrm{EHSA}+\mathrm{SE}+\mathrm{SH}+$ RSPFK+SI,

where GS - genuine savings; GDP - Gross Domestic Product; ACH actual consumption of households; PG public consumption; DFA- the depletion of fixed assets; CNR - consumption of natural resources; EHSA- emissions of harmful substances into the atmosphere;
SE - spending on education; EH expenditure on health; SPEPC- social policy expenditures and physical culture; SI - Spending on innovation. To solve this problem, as with the initial data, we use the materials of the Federal State Statistics Service. The results of our calculations of the true savings of the Russian Federation presented Figure 3.

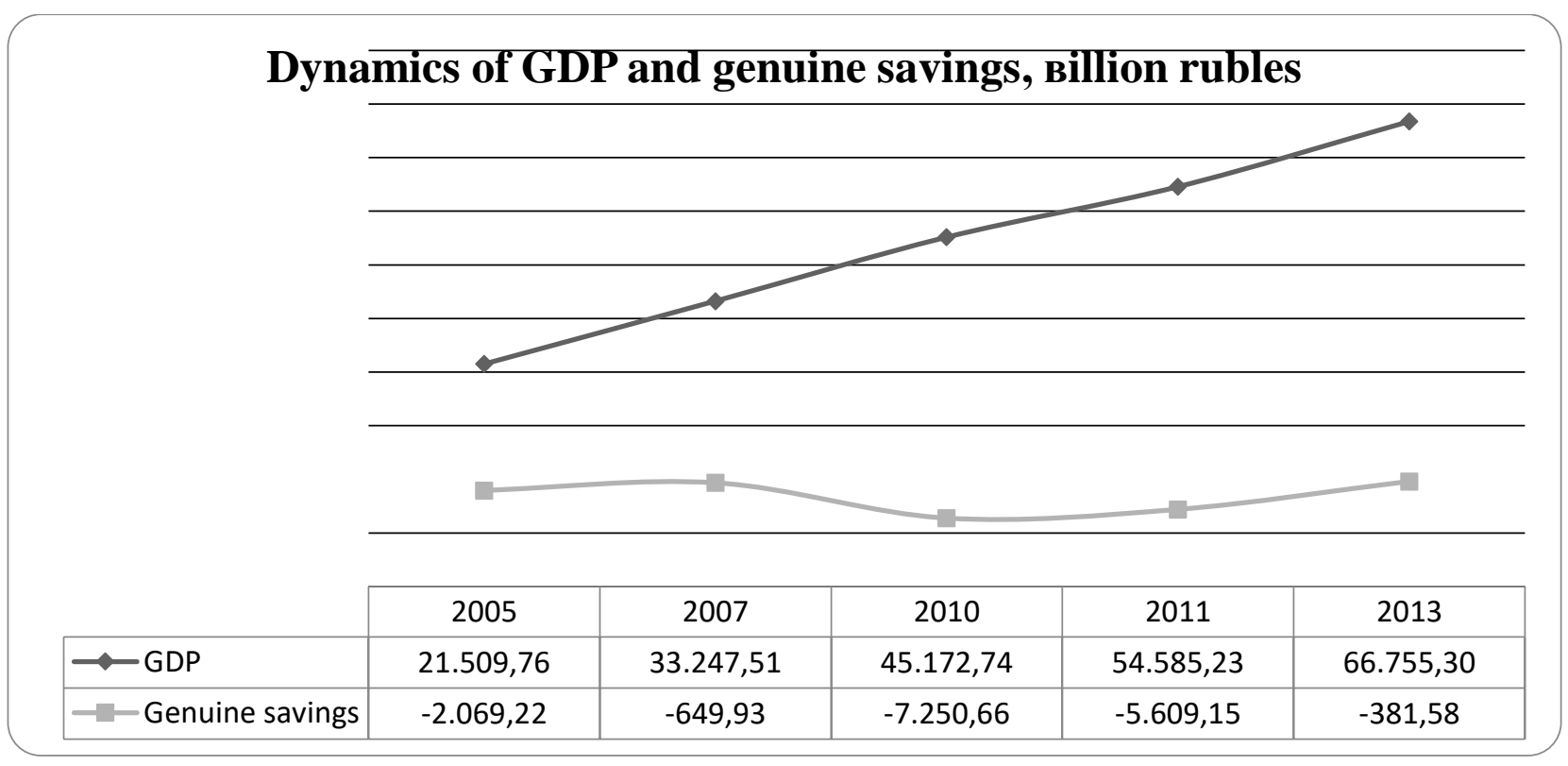

Figure 3: Dynamics of GDP and genuine savings, billion rubles.

As can be seen from Table 1, there was a positive GDP growth rate in the Russian Federation in 2005 - 2013 simultaneously accompanied by negative genuine saving rates.

Despite the serious problems and losses in Russia, in some technology areas it can claim to be a leader and ensure its competitiveness in world markets. We are talking about telecommunications, aviation and space, shipbuilding and nuclear energy, special chemicals and biotechnology, special engineering and microelectronics, and 
new materials and environmental protection.

To implement the innovative potential of the country, reorientation of financing and investment in innovation are paramount for the development of new achievements of scientific and technological progress. The main objective of the investment policy will be the modernization of the production apparatus, and its radical renewal into the forefront of scientific and technical fields.

The main source of finance for innovation, of course, must be domestic savings companies (profit and depreciation). However, given the transitive nature of the Russian economy and the weakness of market institutions to achieve investment and the innovation activity of economic agents, without government stimulus this is unlikely to be possible. To do this, first of all, we must liberate businesses from the taxation of the portion of profits which are directed at implementing innovative programs related to scientific research and experimental development, technical and technological reequipment, the creation of new industries, and promoting the market of innovative products and services.

The taxation of profits used for innovative ends narrows the financial capacity of enterprises, impairs the reproduction of physically and mentally worn out funds and technologies, and reduces the effective demand for investment resources. In addition, it puts innovative enterprises in an unequal, unfair situation with those who engage in purely speculative business or preserve obsolete types of production which squeeze the remains of property inherited for almost nothing via dubious privatization. The budget shortfall in income tax benefits from the system could be offset by an increased tax burden on businesses that ignore the innovative challenges of modernity, which would at the same time be an additional incentive to change the economic behavior of economic agents.

Attracted resources must play an equally important role in the financing of innovation. To solve this problem is impossible without activating the function of credit institutions to promote scientific and technical progress. Despite some positive developments in the activities of commercial banks 
associated with the growth of their capitalization, expanding the range of banking services, and an increase in lending to the real economy, decisive breakthrough has not occurred. Loans are given primarily for working capital; long-term loans are rarely associated with the innovation activities of economic entities.

To stimulate commercial bank lending to the innovation sphere, there should be state guarantees for loans issued, smaller reserve requirements for banks engaged in innovation investments, specialized loan accounts for separate borrowing from their own enterprises in addressing the priority of payment, rate reduction and an increase in refinancing limits, a decrease in income taxes and reserve requirements, and additional mechanisms for credit risk insurance.

However, despite the importance of harnessing the potential of commercial banks in financing, the innovation sphere is unlikely to see a significant result considering incomplete market reforms, the regularly changing rules of the game, distrust of state initiatives, as well as the protracted global economic crisis. This reorientation is unusual for them, involving additional risks under dubious prospects for profit maximization. Most likely, much of the resources of commercial banks, even with the active promotion of the State, will continue to be used in traditional areas.

Consequently, there is a need to search for new mechanisms to ensure a significant inflow of funds in the area of innovation. This problem could be solved by the system of public credit of innovative industries that developed countries receive, by the name of "political financing". The experience of Germany and Japan provides a good example of a successful use of the mechanism, largely to propel them to their post-war "economic miracle."

To do this, we must create a specialized non-profit State Bank, whose purpose would be the financing of innovative projects for the long-term State program of the scientific and technological development of the country. The founders of the bank could be the RF Government, the Bank of Russia, state-owned corporations, commercial banks, and private companies. Founders could give the bank authorized capital of around 10-15 
billion euros, which would allow them to raise up to 100 billion euros of credit resources. The Bank should have the necessary economic independence to prevent lobbying and pressure from the founders, public, and private entities and to lend to only the most effective and promising projects.

The Bank could be refinanced from several sources. First, as for federal funds, investment spending on science should be reflected in a special budget fund and obtain the status of protected items. In turn, the sources of the budgetary fund would be: a) related foreign loans guaranteed by the government of the Russian Federation; b) deductions from domestic borrowing; c) cash proceeds from the sale of State property.

Secondly, let's address the financial resources of the enterprises themselves. A prerequisite for innovation credits should be the enterprise's own funds (totaling perhaps $30-40 \%$ of total funding). If businesses do not have the necessary means, formed by the expense of reinvested profit and depreciation, they will have to accumulate them for a certain period, perhaps via bank investments.
Third, from government investment bonds. They could be sold among the commercial banks, investment firms, non state pension funds, insurance companies, as well as among the population. State guarantees should provide relative cheapness for attracting credit resources.

The basic principles of credit policy should be: concessional lending; long-term loans; providing loans for the implementation of innovative projects in priority sectors; competitive selection of investment projects; formalization of procedures for granting loans, and multilevel and collegial decision-making. It is necessary to prevent the possible commercialization of the bank. Otherwise, we will get another structure, formally located under the "roof of the state ", but actually working in order to enrich the bank's management.

The development of the innovative factor of economic growth is impossible without solving the problem of capital flight from the country. In the past six years net capital outflows reached $\$ 470$ billion. This amount is almost equal to the country's gold reserves. To change the negative trend some things are necessary: a favorable 
investment climate; to guarantee the irreversibility of market reforms; an implementation of the de facto rule of law, a separation of powers, an independent judiciary; an eradication of corruption; and the protection of property rights.

In the same arena is the problem of attracting foreign investment, and strengthening its innovation orientation. Among the obstacles to foreign investment besides those mentioned above are the lack of tangible benefits for foreign investors and guarantees from the worsening conditions in Russia.

Tax benefits could play an important role in attracting foreign investment. At the same time, their role should not be overestimated since tax incentives are not the decisive factor in deciding on the placement of new investments. More important to investors are political and economic stability in the country, the state of growth of the national economy, the stability of the national currency, and the quality of labor (at relatively low wages). And only ceteris paribus do significant tax benefits prove an advantage for a country.

\section{CONCLUSIONS}

The transition to an innovative economy is a complex and long-term process that requires the mobilization of all available resources, creating a favorable economic, financial, and institutional environment, and the organic interaction of market selfregulation and government regulation.

\section{ACKNOWLEDGMENT}

The work is performed according to the

Russian Government Program of Competitive Growth of Kazan Federal University.

\section{REFERENCES}

Smith A. (1904) Studies on the nature and causes of the wealth of the people. Available at http://econlib.org/library/Smith/smWN2 $\underline{0 . h t m l}$

Solow, R.M. (1956) A contribution to the theory of economic growth. Quarterly Journal of Economics, p. 6594.

Kuznets S. (1973) Modern Economic Growth: Finding and Reflections, American Economic Review, № 6. Free Press. 
Schumpeter J. (1982) The Theory of

Economic Development, Progress

Publishers, 455 p.

M. Porter (2000) Competition, Publishing House "Williams", Free Press.

Nurtdinov R.M., Nurtdinov A.R. (2014) Assessment of the Dynamics of Growth Factors in Russia, Mediterranean Journal of Social Sciences. Vol. 5, № 18, p. $361-366$

Nurtdinov R.M., Nurtdinov A.R., N.G. Kucevol. Effect of EnvironmentalEconomic Imbalances at Sustainable Development of the Russian Federation // Mediterranean Journal of Social Sciences, Vol.6.

(Online)http://www.mcser.org/journal/i ndex.php/mjss/issue/view/103

Huning, S., Naumann, M., Bens, O., Hüttl, R.F. (2011) Transformations of modern infrastructure planning in rural regions: The case of water infrastructures in Brandenburg, Germany, European Planning Studies 19 (8), p. 1499-1516
Safiullin L.N., Ismagilova G.N., Safiullin N.Z., Bagautdinova N.G. (2012) The development of welfare theory in conditions of changes in the quality of goods and services, World Applied Sciences Journal 18, p. 144-149.

Bagautdinova N.G., Gafurov I.R., Novenkova A.Z. (2013) The transformation of region's economic area governed by the development of industrial region, World Applied Sciences Journal, 25(7), p. 113-117

Glebova I.S., Khamidullina A.M, Anisimova E.A. Correlation of Balanced Socio-Economic Development of the City and Its Attractiveness (in the Case of Russian Cities with Population over a Million Citizens) 2015 // Mediterranean Journal of Social Sciences, Vol.6. ISSN 2039-

9340.(Online)

http://www.mcser.org/journal/index.php /mjss/issue/view/103

Gauselmann, A., Marek, P. (2012) Regional determinants of MNE's location choice in post-transition economies, Empirica39 (4), p. 487-511 